\title{
Information System Strategic Planning and Information Technology in Organizer Event Service Company at Surabaya
}

\author{
Maulidina Rahmawati Surya ${ }^{1}$ and R.V Hari Gunardi ${ }^{1}$
}

\begin{abstract}
The level of business competition of an organization at this time is increasingly high. This is caused by economic factors and the presence of new competitors. Many organizations do not have the ability to deal with these conditions. Management of innovation and improvement that is limited by time, cost and quality are referred to as project management. Many methods, techniques, and tools have been developed, covering all aspects of project management from start to finish. If project management practices are implemented correctly, it allows for increased efficiency and productivity. In this study, how project management is implemented by evaluating the use of project management tools and effectiveness in supporting projects that run in the organization of PT. XYZ. This is done by distributing questionnaires to 30 respondents involved in the project that was carried out in 2018 to the present. The analytical method used is descriptive analysis and inferencing using SPSS used to determine the use of tools and project management techniques. Results in this study project management tools and techniques most often used by PT $X Y Z$ are progress reports, activity lists, and project charter. From the position positional factors and managed project costs factors are have significant value that affects the use of project management tools and techniques at PT XYZ in Indonesia.
\end{abstract}

Keywords-Project Management, Project Management Tools and Techniques, Project Management Implementation.

\section{INTRODUCTION}

Business competition is very tight as now the company must have competitive advantage. IT is one of the factors that can support the progress of a company with a business strategy. There are several benefits in implementing an IS / IT within an organization. First, improve work efficiency by automating various processes that manage information. Furthermore, increasing the effectiveness of management by satisfying information needs for decision making. Another benefit is improving competitiveness or increasing the organization's competitive advantage by changing the style and way of doing business [1]. This company is engaged in event organizer, digital and exhibition services. This company has area business partners throughout Java to Bali. Marketing media for online promotion is currently a website but not optimal, for business activities in the

\footnotetext{
${ }^{1}$ Maulidina Rahmawati Surya and R.V Hari Gunardi are with Departement of Management Technology, Institut Technology Sepuluh Nopember, Surabaya, Indonesia. Email:maulidinarahmawati14@gmail.com.
}

implementation of projects still manually requires a long time to access and manage information and difficult to adapt to the increasing volume of information along with the increase in business activities carried out. The role of IT in this case is quite significant, because with IT all processes that are initially manual can turn out to be wellautomated.

The impact that is caused is the accumulation of data, the recapitulation of data in each division has no relevance and inaccurate results of data processed in each section will cause duplication of data so that it can inhibit the management of information management for decision making. As for supporting the business process, it has not used IT facilities so that the data has not been connected with other parts to support its business processes. From the business activities of the company's project work from preproduction, production to post- production (reports), it is necessary to coordinate information between divisions. As a result, the event report process that is billed late is overdue, bill payments are not on schedule from the client's side.

The problem that occurs in companies is that the application of IS / IT is currently not aligned with the company's business strategy, only based on the needs of each part, not based on IS / IT planning. Planning is needed so that the investment spent on IS / IT is in accordance with the needs and provides benefits measured from the achievement of the company's goals and objectives [2]. From the background described, some problems are found: what are the situations, conditions and competition business faced by event organizer services. How is the IS / IT strategy in accordance with the organization's strategy so that it can support the performance of the event organizer service company. Strategic plan is expected that it will contribute to internal development and the development of reading strategies of the IS / IT event organizer services in the future. Knowing the IS / IT requirements of each company division so that application management is in accordance with its portion to improve service and gain competitive advantage with other EOs in accordance with the company's vision, mission, goals. 


\section{LITERATURE RIVIEW}

\section{A. Previous Research}

There has been a previous study that assessed strategic plans and information technology [3]. This research was conducted because the information system in PT. Ritrans Cargo has not been able to connect between division one with other divisions so that the resulting information cannot be integrated properly and data duplication occurs causing information inaccuracies. Tools used for business strategy analysis with PEST, PLC (Product Life Cycle), BCG (Boston Consulting Group), Five Porter analysis, SWOT and CSF analysis. The conclusion of the research is in quadrant 3 which indicates that the company has great opportunities and large internal weaknesses, so the company's strategy is focused on utilizing the opportunities it has to minimize weaknesses. The second study was about information technology strategic planning in a children's hospital [4]. IT strategic planning makes hospitals analyze hospital environments and build an operational plan for IT implementation. The steps taken are studying the current condition of IT, describing future desires, and mapping the work that must be done to get the goal. The results obtained from the IT field are a strategic plan for the next 5 years to improve services from children's hospitals in Ontario.

The next research is IS / IT strategic planning at PT. BerlianJasa Terminal Indonesia [5]. This research is engaged in container terminals. The purpose of this research is to make strategic IS / IT planning that is consistent with its business strategy using Ward and Peppard methods. The results of this study are located coordinates $(2.95,2.81)$, meaning that the focus of the proposed strategy is an SO strategy using internal power to take advantage of external opportunities, overcome internal weaknesses, and avoid external threats.Based on several previous studies, in this study there was a renewal at the last stage, namely determining the priority scale of future application portfolios using the AHP method.

\section{B. Strategic planning}

Strategic planning is a management that is used to manage current conditions to project conditions in the future, so that the strategic plan is a guide that can be used by the organization from current conditions to work towards the next 5 to 10 years [6]. Whereas according to Cassidy [2], strategic planning is a key component for the success of each information system function and is an important factor in helping companies achieve their business goals. Meanwhile, according to Turban [7], strategic planning is a set of long-term goals that describe system and architectural goals technology to achieve company goals.

Based on some of the above meanings, it can be concluded that strategic planning is a long-term process and in a certain period of time where the planning is useful to help organizations or companies in conducting corporate strategic planning in the future to help develop business processes and integrate all business activities so that they can achieve organizational goals.

\section{METHOD}

The methodology used refers to the Ward and Peppard [1] methodology with the research stage as shown below:

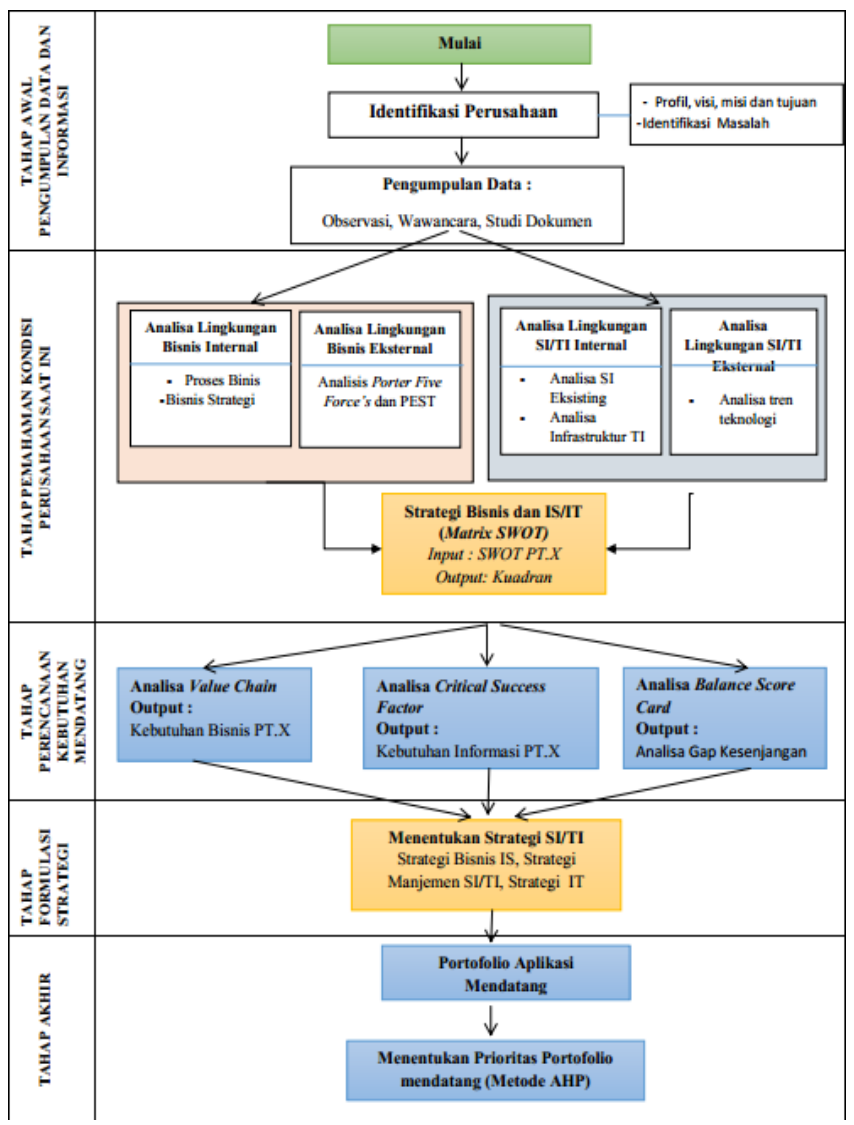

Figure 1. Research methodology

From Figure 1, the IS / IT strategic planning that refers to Ward and Peppard with the research stages are as follows: The initial stage of collecting data and information needed, understanding the current condition of the company by analyzing the internal and external business environment and IS / IT, then conduct a SWOT analysis to determine its strategic issues. The next step is to determine the organization's value chain, determine future needs through BSC analysis of the strategic issues that have been determined, then determine the factors that are the key to the success of strategic issues with the Critical Success Factor analysis, for further strategic activities. From these analyzes, it is known that the information needs that are translated into potential applications will be developed. Then these applications are mapped on McFarland's matrix to determine its contribution to the organization. The final stage is to produce an implementation plan 
recommendation by determining the priority of future application portfolios using AHP.

\section{A. Early Stage}

The initial stage contains company identification, data collection. Identification and problem analysis are considered and materials determine the portfolio application recommendations.

\section{1) Company Identification}

This literature study is carried out by identifying the profile, vision, mission and objectives of the company related to IS / IT planning so that problems faced by the company that are currently running are obtained. Identification and analysis of problems can later be used as portfolio application recommendation materials, so that obtain knowledge in progress.

\section{2) Data Collection}

Data collection is done in two ways, namely observation (company profile documents, IT management) and interviews (knowing the problems that exist in the company).

\section{B. Analysis of the Current Condition of the Company}

\section{1) Internal Business Environment Analysis}

This stage contains a description of the analysis of business strategies that are used to obtain company business direction and goals that can influence information system needs in the future. Inputs to this analysis are company documents in the form of vision, mission, goals, objectives, organizational structure and event organizer business flow. The results of this company that the strategic goals that have been carried out include developing a marketing network and improving the handling of services to clients and providing employee performance targets to be motivated by knowing the EO internal business so that the company can provide the best marketing services to clients to be competitive to similar companies. From the description above the company has a lot of strength. The results of this analysis are used as input to the SWOT analysis in aspects of opportunities and threats that can be seen in Table 1

TABLE 1.

RESULT INTERNAL BUSINESS ENVIRONMENT ANALYSIS

\begin{tabular}{cl}
\hline \hline Code & \multicolumn{1}{c}{ Analysis Result } \\
\hline BI1 & PT.X's organizational structure adheres to line organizations \\
BI2 & $\begin{array}{l}\text { Selection of strategic office locations, in urban centers, access } \\
\text { roads, campuses, shopping. }\end{array}$ \\
BI3 & $\begin{array}{l}\text { Has several management programs in improving innovation, } \\
\text { creative, effective and performance efficiency. }\end{array}$ \\
\hline \hline
\end{tabular}

2) External Business Environment Analysis

This analysis consists of PEST and Porter five force analysis, input from this stage begins with literature studies, observation and study of company documents. The output of this analysis is the identification of opportunities and the position of the company seen from the company's external factors.

TABLE 2.

RESULT PEST ANALYSIS

\begin{tabular}{|c|c|c|}
\hline Analysis Aspect & Code & Result of Analysis \\
\hline \multirow[t]{4}{*}{ Politics } & PEST1 & $\begin{array}{l}\text { Event Organizer is always related to politics, especially in the tax sector. This is because the event held is indoor or } \\
\text { outdoor. So that it must have a establishment permit from the government and is required to pay a certain amount of tax. }\end{array}$ \\
\hline & PEST2 & $\begin{array}{l}\text { Licensing also greatly affects the event organizer companies where events or advertisements cannot be installed anywhere } \\
\text { before their establishment must have their licensing business completed }\end{array}$ \\
\hline & PEST3 & $\begin{array}{l}\text { Regulations regarding employment in the field of events where employee safety is important. The minimum wage also } \\
\text { follows the standards set by the government }\end{array}$ \\
\hline & PEST4 & $\begin{array}{l}\text { Politics in the event industry or advertising does not always put pressure on EO companies. All existing activities } \\
\text { require an average EO media. Here, of course, companies must be good at capturing opportunities. }\end{array}$ \\
\hline \multirow[t]{3}{*}{ Economy } & PEST5 & $\begin{array}{l}\text { Economic improvement is considered good for business growth opportunities, especially supporting product sales such as } \\
\text { product promotion }\end{array}$ \\
\hline & PEST6 & $\begin{array}{l}\text { economic growth also influences the performance of the company, especially when the prices of raw materials increase, } \\
\text { causing the profits of the company to wane and usually only a little profit. }\end{array}$ \\
\hline & PEST7 & $\begin{array}{l}\text { Exchange rate fluctuations also do not have much influence on companies because companies do not penetrate the export- } \\
\text { import sector. }\end{array}$ \\
\hline \multirow[t]{3}{*}{ Social } & PEST8 & $\begin{array}{l}\text { Not having awareness about event organizer services, because there is still an understanding that using EO services must } \\
\text { spend a large amount of funds. }\end{array}$ \\
\hline & PEST9 & $\begin{array}{l}\text { Demand is increasing every year, the growing economy in Indonesia, more and more new efforts that make its own } \\
\text { opportunities for EO services. }\end{array}$ \\
\hline & PEST10 & $\begin{array}{l}\text { Working environment conditions also influence the company. Not an environment where employees work within the } \\
\text { company. But there are a number of problems with unexpected work. This certainly causes eo companies to have to spend } \\
\text { more money on unnecessary needs. }\end{array}$ \\
\hline \multirow[t]{2}{*}{ Technology } & PEST11 & $\begin{array}{l}\text { Most of the world of business is directly affected by the influence of this fast information technology. Companies are } \\
\text { required to be able to follow and adjust the pace of the development of information technology }\end{array}$ \\
\hline & PEST12 & $\begin{array}{l}\text { Dependence and the high growth of the internet are quite high, is an opportunity and opportunity for event business } \\
\text { because it uses information technology facilities for marketing and promotional purposes in increasing sales. }\end{array}$ \\
\hline
\end{tabular}


TABLE 3.

RESUlt PORTER's FIVE FORCES ANALYSIS

\begin{tabular}{lll}
\hline \hline Analysis Aspect & Code & \multicolumn{1}{c}{ Result of Analysis } \\
\hline $\begin{array}{l}\text { Threat of new entrants } \\
\text { PF1 }\end{array}$ & $\begin{array}{l}\text { The emergence of similar companies with large capital and has the leading information technology to support the } \\
\text { implementation of the event so that it can be a decline in demand for this company's services. }\end{array}$ \\
$\begin{array}{l}\text { Bargaining power of } \\
\text { buyers }\end{array}$ & PF2 & $\begin{array}{l}\text { Has a high bargaining power because of the diverse needs of clients adjusting to the promotional budget provided by } \\
\text { the company. }\end{array}$ \\
$\begin{array}{l}\text { Bargaining power of } \\
\text { suppliers }\end{array}$ & PF3 & $\begin{array}{l}\text { Offering high-quality products, of course, has more appeal to Clients because it has a high value. } \\
\text { The threat of uncertain raw material prices with the quality offered by the company for the price of raw materials } \\
\text { sold also affects the company.affects the company. }\end{array}$ \\
$\begin{array}{l}\text { Threat of substitute } \\
\text { products or services }\end{array}$ & PF5 & $\begin{array}{l}\text { Having high strength because of EO services that offer lower prices with the usual quality of event services. } \\
\text { However, for the prestige event this company is superior. }\end{array}$ \\
$\begin{array}{l}\text { Rivalry among } \\
\text { existing competitors }\end{array}$ & PF7 & $\begin{array}{l}\text { The use of management information systems that are still minimal and not maximized. So the alternative is to } \\
\text { change or improve its use as an online media channeling system (e-mail, bookkeeping, promotions, etc.) } \\
\text { The threat level of business competitors is high because it has a low entry barrier. Seasonal demand for regional } \\
\text { government, wedding, promotion is where opportunities for event organizer services arise where services will } \\
\text { certainly be used to become partners who provide media. }\end{array}$ \\
\hline \hline
\end{tabular}

\section{- PEST Analysis}

PEST analysis is used to determine the external conditions of business that occur today in environments outside PT. X that can affect the company. The results of this analysis are used as a reference in determining business strategies to achieve the company's strategic objectives and are used as input for external factors in the SWOT analysis can seen Table 2.

\section{- Porter's Five Force Analysis}

Porter's five force analysis is used to map the position of the company in the event organizer business competition. Demographic conditions, especially population factors and good economic levels have the opportunity to support the development of business activities in the future. This analysis is reviewed from five factors used as input for external factors in the SWOT analysis can seen Table 3.

\section{3) Analysis of Internal SI / IT Environment}

TABLE 4.

RESULT OF ANALYSIS OF INTERNAL SI / IT ENVIRONMENT

\begin{tabular}{ll}
\hline \hline Code & \multicolumn{1}{c}{ Description } \\
\hline IST1 & There is no current IS / IT management policy \\
IST2 & There are no IT divisions or resources that have IT expertise \\
IST3 & $\begin{array}{l}\text { Applications currently available are still simple and } \\
\text { manually using Microsoft office }\end{array}$ \\
IST4 & Has no IS / IT planning blueprint \\
IST5 & Does not have a company IS / IT strategic plan \\
\hline \hline
\end{tabular}

This analysis includes an analysis of the condition of the IS / IT organization especially those related to resources from the perspective of HR competencies that do not yet have an IT team division to support information technology and resources in the form of available information technology infrastructure that has limitations on network infrastructure is still a common form with connecting the internet from Telkom is then accessed to several computers. The event organizer company portfolio has several services that are implemented but it is still simple to use Microsoft office and a simple website and is carried out by SI / IT in each quadrant using Mc Farland tools for. The results of internal IS / IT can be seen in the Table 4

4) SI / IT External Environmental Analysis

This analysis is an IT / IT technology trend in the company. By using this analysis, it is expected to obtain a variant of potential applications that can be applied for the future to the event organizer in Surabaya. As for information technology trends that are currently being used by other companies and can be applied to event organizers in Surabaya, among others: web applications, cloud computing, VPN. The results of eksternal IS / IT can be seen in the Table 5.

TABLE 5.

RESULT OF ANALYSIS TREN TECHNOLOGY INFORMATION

\begin{tabular}{cl}
\hline \hline Kode & \multicolumn{1}{c}{ Deskripsi } \\
\hline TT1 & $\begin{array}{l}\text { The application of web-based applications is lighter and can be } \\
\text { accessed quickly through a browser and internet connection. }\end{array}$ \\
TT2 & $\begin{array}{l}\text { Application of cloud computing can help store data centrally, } \\
\text { secure security, ease of data access from anywhere, and cost } \\
\text { savings. }\end{array}$ \\
TT3 & $\begin{array}{l}\text { Application of cloud computing can help store data centrally, } \\
\text { secure security, ease of data access from anywhere, and cost } \\
\text { savings. }\end{array}$ \\
\hline \hline
\end{tabular}

After conducting internal and external analysis of the company's business environment as well as internal and external IS / IT analysis, the next step is to carry out a SWOT analysis to find out the strengths, weaknesses, opportunities and threats that occur in the event organizer company.

\section{5) SWOT Analysis}

Analysis of internal factors, the aspects used are the approaches of the existing fields in the company, namely business, finance, human resources, organization and management, event facilities and equipment, technology, and law and public relations results of IFAS analysis can be seen in Table 6 . While the analysis of external factors can be seen in Table 7. Tables 6 and 7 obtained IFAS values 1.61 and EFAS values 2.05. 
TABEL 6.

HASIL ANALYSIS IFAS

\begin{tabular}{|c|c|c|c|c|c|c|}
\hline \multicolumn{2}{|c|}{ Factor Internal Strategy } & \multirow{3}{*}{ Source } & \multirow{3}{*}{\multicolumn{2}{|c|}{ Weight }} & \multirow{3}{*}{ Rating } & \multirow{3}{*}{$\begin{array}{l}\text { Weighted } \\
\text { Value }\end{array}$} \\
\hline \multicolumn{2}{|c|}{ Strenght Analysis } & & & & & \\
\hline Code & Description & & & & & \\
\hline S1 & $\begin{array}{l}\text { This Event Organizer has business legality that is able to support legal certainty in the conduct of } \\
\text { business activities carried out }\end{array}$ & \multicolumn{2}{|c|}{ WA1 } & 0.11 & 4 & 0.44 \\
\hline $\mathrm{S} 2$ & The organizational structure adheres to line organizations & \multicolumn{2}{|c|}{ BI1 } & 0.09 & 3 & 0.24 \\
\hline S3 & The program is made clear and conceptual & \multicolumn{2}{|c|}{ WA2 } & 0.11 & 3 & 0.4 \\
\hline S4 & Offering good quality products & \multicolumn{2}{|c|}{ WA3 } & 0.11 & 4 & 0.3 \\
\hline S5 & Marketing employees are motivated at work & \multicolumn{2}{|c|}{ WA5 } & 0.1 & 3 & 0.27 \\
\hline \multirow[t]{2}{*}{ S6 } & Owning a Company Website & \multicolumn{2}{|c|}{ WA9 } & 0.11 & 4 & 0.44 \\
\hline & SubTotal & & & & & 2.09 \\
\hline \multicolumn{7}{|c|}{ Weakness } \\
\hline W1 & There is no current IS / IT management policy & \multicolumn{2}{|c|}{ IST1 } & 0.05 & 1 & 0.05 \\
\hline W2 & There are no IT divisions or resources that have IT expertise & \multicolumn{2}{|c|}{ IST2 } & 0.04 & 1 & 0.04 \\
\hline W3 & The existing applications are still simple and manually using Microsoft & IST? & 0. & 06 & 2 & 0.12 \\
\hline W4 & Don't have an IS / IT planning blueprint & IST 4 & 0. & 04 & 1 & 0.04 \\
\hline W5 & Don't have a company IS / IT strategic plan & ISTs & 0. & 04 & 1 & 0.04 \\
\hline W6 & Promotional media used are less developed & WA & 0. & 05 & 1 & 0.05 \\
\hline W7 & Lack of utilizing the use of technology to support organizational activities & $\mathrm{WA}^{\top}$ & 0. & 04 & 1 & 0.04 \\
\hline W8 & Companies sometimes duplicate data & WAs & 0. & 05 & 2 & 0.1 \\
\hline & SubTotal & & & & & 0.48 \\
\hline & Total & & & & & 2.57 \\
\hline & $\begin{array}{l}\text { TABEL } 7 . \\
\text { HASIL ANALYSIS EFAS }\end{array}$ & & & & & \\
\hline Factor & Internal Strategy & & & & & \\
\hline Opport & tunity Analysis & & Source & Weight & t Rating & $\begin{array}{l}\text { Weighted } \\
\text { Value }\end{array}$ \\
\hline Code & Description & & & & & \\
\hline $\mathrm{O} 1$ & $\begin{array}{l}\text { Economic improvement is considered good for business growth opportunities, especially supporting } \\
\text { product sales such as product promotion }\end{array}$ & & PEST6 & 0.11 & 4 & 0.44 \\
\hline $\mathrm{O} 2$ & Selection of strategic office locations, in urban centers, access roads, campuses, shopping & & BI2 & 0.08 & 3 & 0.24 \\
\hline $\mathrm{O} 3$ & $\begin{array}{l}\text { Seasonal demand for regional government, wedding, promotion is where opportunities for event organ } \\
\text { services arise }\end{array}$ & nizer & PF7 & 0.11 & 4 & 0.44 \\
\hline $\mathrm{O} 4$ & $\begin{array}{l}\text { The application of web-based applications is lighter and can be accessed quickly through a browser and } \\
\text { internet connection }\end{array}$ & & TT1 & 0.09 & 3 & 0.27 \\
\hline O5 & $\begin{array}{l}\text { The application of cloud computing can help store data centrally, secure security, ease of data access fr } \\
\text { anywhere, and cost savings }\end{array}$ & rom & TT2 & 0.09 & 3 & 0.27 \\
\hline O6 & $\begin{array}{l}\text { Implementation of VPN can maintain confidentiality, maintain the integrity of data traffic and } \\
\text { autenthification of the data sending sources it receives. }\end{array}$ & & TT3 & 0.09 & 3 & 0.27 \\
\hline O7 & The company offers prestige events & & PF5 & 0.09 & 3 & 0.27 \\
\hline O8 & Maintain good relations with clients & & WA4 & 0.09 & 3 & 0.27 \\
\hline & SubTotal & & & & & 2.47 \\
\hline & Threat & & & & & \\
\hline $\mathrm{T} 1$ & $\begin{array}{l}\text { Not having awareness about event organizer services, because there is still an understanding that using } \\
\text { services must spend a large amount of funds }\end{array}$ & EO & IST1 & 0.05 & 2 & 0.1 \\
\hline $\mathrm{T} 2$ & Working environment conditions also affect the company and employees & & IST2 & 0.04 & 1 & 0.04 \\
\hline $\mathrm{T} 3$ & $\begin{array}{l}\text { Companies are required to be able to follow and adjust the pace of the development of information } \\
\text { technology }\end{array}$ & & IST3 & 0.04 & 1 & 0.04 \\
\hline $\mathrm{T} 4$ & $\begin{array}{l}\text { The emergence of similar companies with large capital and has the leading information technology to } \\
\text { support the implementation of the event }\end{array}$ & & IST4 & 0.05 & 2 & 0.1 \\
\hline
\end{tabular}


The $1^{\text {st }}$ International Conference on Business and Management of Technology (IConBMT)

August 3rd 2019, Institut Teknologi Sepuluh Nopember, Surabaya, Indonesia

T5 The threat of raw material prices is uncertain with the quality offered by the company

IST5

T6 Has a high bargaining power because of the diverse needs of clients

\begin{tabular}{ccc}
0.04 & 1 & 0.04 \\
0.05 & 2 & 0.1 \\
\hline & & $\mathbf{0 . 4 2}$ \\
\hline & & $\mathbf{2 . 8 9}$ \\
\hline
\end{tabular}

These results are used as coordinates on the SWOT matrix, so that coordinates 1.61 for the $\mathrm{X}$ axis and 2.05 for the $\mathrm{Y}$ axis are obtained.

Based on the coordinates in Figure 2, that the company's position is in quadrant $\mathrm{I}$, which means the company supports aggressive strategy activities by increasing the services and facilities in the event organizer company and expanding the relationship of event organizer service users so that the event organizer sales target increases. Therefore the strategy applied in this condition is a growth- oriented strategy to exploit these benefits, namely by using the SO strategy.

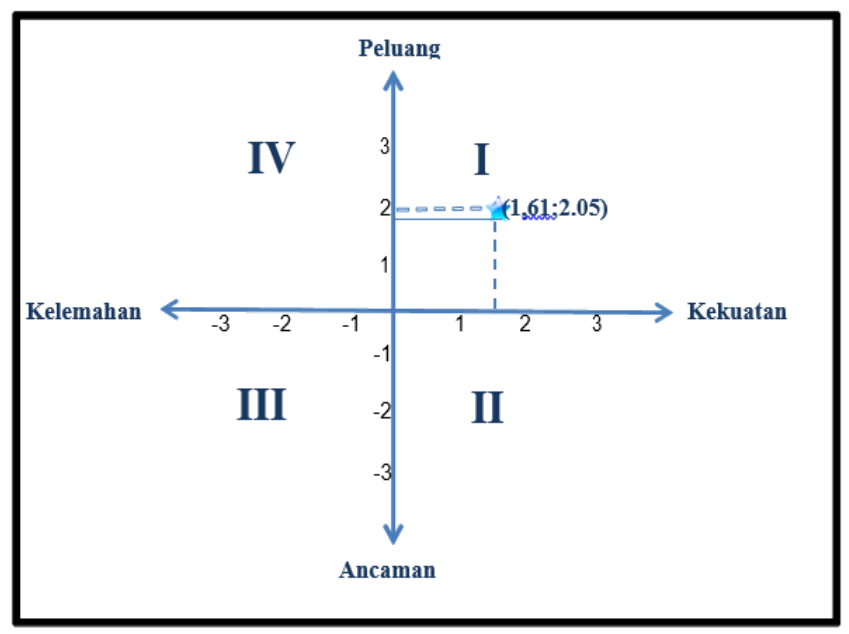

Figure 2. Matrix Swot

Figure 2 shows that the company's position is in quadrant I, which means that the company supports aggressive strategy activities which have multiple opportunities and have a variety of strengths that can support in exploiting these opportunities, overcoming internal weaknesses, and avoiding external threats. The effort that can be done by PT. X is by increasing the services and facilities available at the event organizer company and expanding the relationship of event organizer service users so that the event organizer's sales target will increase. Therefore the strategy applied in this condition is a growth-oriented strategy to exploit these benefits, namely by using the SO strategy.

\section{Identification of Future Needs}

\section{1) Value Chain Analysis}

Identification of potential business needs for each work unit. For this reason, mapping each activity into the processes and parts involved and the potential business needs related to minimizing the weaknesses discussed in the SWOT analysis presented in Table 8 and Table 9.

2) Balanced Scorecard Analysis

Balanced scorecard analysis is taken from the value chain mapping and then identifies the map strategy, which is a qualitative statement in the form of a strategy program to realize the strategy objectives.

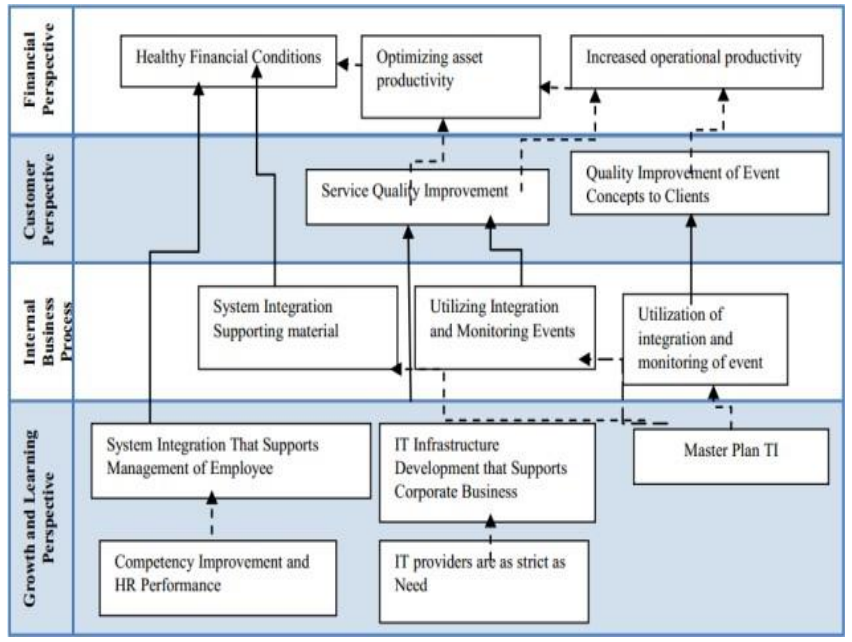

Figure 3. BSC

\section{3) Critical Success Factor Analysis}

After the potential business needs are successfully identified, then an analysis is carried out to determine the critical success factors, the size of each potential business need and identify its information needs. For example, the tenth business needs based Competency Enhancement and HR performance are considered to have the most influence on the suitability of employee competencies with employee work.

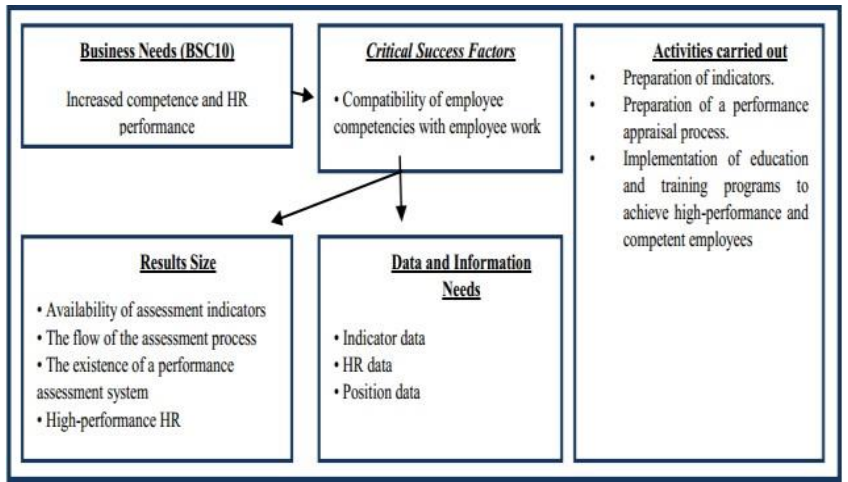

Figure 4. CSF Scema of BSC Competency Enhancement and HR performance 
TABLE 8.

MAPPING OF MAIN ACTIVITIES

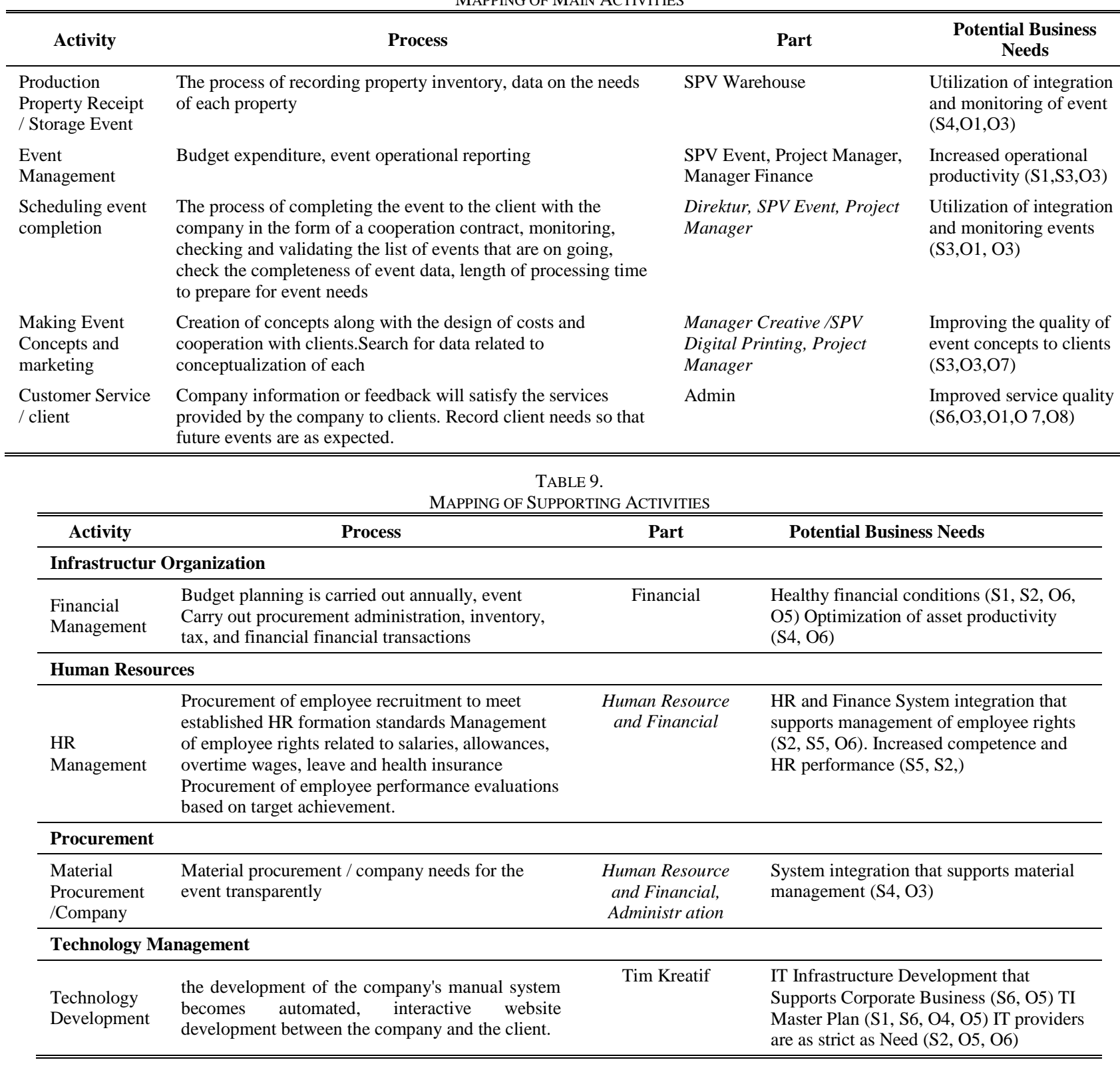

\section{RESUlT AND DisCUSSION}

\section{A. Strategy Formulation}

\section{1) SI Business Strategy}

From the CSF scheme that was produced, data and information needs can be known for every potential business need for event organizers in Surabaya. The identified data and information needs are determined by the information system requirements, in the form of improvements, namely the website and the addition of new information systems that can meet business needs, including: E- Proc, Financial Management, HR Administration, Event Package Organizer.

\section{2) IT strategy}

The recommendations proposed are as follows: adding a web server to procure an online booking module, server colocation for a database or application server, adding a network security system by implementing a gateway, cloud computing utilizing a combined use of computer technology in a network with development-based. This serves to facilitate users in terms of data efficiency and cost savings, data is stored on the server centrally, flexible in accessing data as long as it is connected to the internet. 


\section{3) IS / IT Management Strategy}

The formulation of the IS / IT strategy in Baba is used as a reference for management in determining policies relating to company IS / IT, such as: Making an IT Master Plan, Providers who are in harmony with needs.

4) Upcoming portfolio

The results of the application portfolio are obtained from the validity and reliability test first with the number of 10 respondents and 6 questions in each application using SPSS tools. Based on these results, the application is categorized by the provisions of the McFarland Strategic Grid can be seen Table 10.

TABLE 10.

RESUlts OF THE MCFARLAND STRATEGIC GRID PORTOFOLIO OF UPCOMING APPLICATIONS

\begin{tabular}{ll}
\hline \multicolumn{1}{c}{ Strategic } & High Potential \\
\hline $\begin{array}{l}\text { Pengelolaan } \text { invoice dan Piutang* } \\
\text { Layanan Personalia* }\end{array}$ & \\
$\begin{array}{l}\text { Event Package Organizer** } \\
\text { Financial Management** }\end{array}$ & Website* $^{*}$ \\
\hline \multicolumn{1}{c}{ Key Operational } & \multicolumn{1}{c}{ Support } \\
\hline Pengelolaan pengadaan barang* & Layanan Pengelolaan \\
Layanan Administrasi* & Keuangan dan \\
E-Proc** & Akuntansi* HR \\
& Administration \\
\end{tabular}

Information :

* Applications that are currently still in use

** Recommended applications to support business strategies

5) Determining Upcoming Portfolio Priorities

Using AHP with results from weighting priorities between application portfolios, pairwise comparison matrices, CI consistency test $=0.088$ and $\mathrm{CR}$ approaching 0.1, which is 0.098. The weight of the Application Portfolio has been calculated using AHP and can be concluded with the priority scale as follows:

TABLE 11.

Weight AND CRITERIA ELEMENT PRIORITIES BASED ON FUtURE APPLICATION PORTOFOLIO

\begin{tabular}{lcc}
\hline \hline Portofolio Aplication & Weight & Priority \\
\hline Aplikasi Event Package Organizer & 0.44 & $\mathbf{1}$ \\
Aplikasi Financial Management & 0.34 & $\mathbf{2}$ \\
Aplikasi HR Admnistration & 0.14 & $\mathbf{3}$ \\
Aplikasi E-Proc & 0.07 & $\mathbf{4}$ \\
\hline \hline
\end{tabular}

\section{CONCLUSION}

\section{A. Conclusions}

Based on the problems that arise, and discussion in the previous stage, conclusions can be taken as follows.

1. The process of analysis is divided into several stages, namely analysis of the current condition of the company, identification of future needs and strategy formulation.
2. Analysis of the current condition of the company produces output in the form of a SWOT analysis to be used. Identification of future needs results in BSC, CSF analysis and gap analysis, which are used as inputs in strategy formulation. The results of strategy formulation are SI strategy, IT strategy, IS / IT management strategy and application portfolio. The last stage, determine the priority scale of the application portfolio using the AHP method.

3. Based on the results of the current analysis, a SWOT matrix is located in the coordinates $(1.61,2.05)$, meaning that the focus of the proposed strategy is the SO (strengths opportunities) strategy. In other words, the strategy that must be done at a later stage is to use internal power to take advantage of external opportunities, overcome internal weaknesses, and avoid external threats.

4. Analysis of the SI strategy resulted in a renewal recommendation for one application, namely the website and four new applications to support the company's business strategy, namely the Application of Event Package Organizer, Financial Management, HR Administration, E-Proc.

5. Analysis of IT strategies produces recommendations for the use of colacation servers, the addition of web servers, the addition of network security systems, cloud computing.

6. Analysis of the IS / IT management strategy produces recommendations regarding IT master plans and IT providers that are in line with needs.

7. Determining Priority of Application Portfolio Upcoming using AHP calculation, the event package organizer application gets the weight of 0.44 so that it becomes the first priority scale that is recommended to be applied in the company by looking at the limitations of the budget and human resources. Furthermore, the second priority financial management application with a value of 0.34 while the HR Administration application is prioritized with a value of 0.14 .

\section{B. Recommendations}

From the results of the study, some suggestions for further research can be proposed, including:

1. Suggestions for companies are to improve performance between departments so that they can anticipate emerging risks and periodically evaluate the system so that the company's business objectives are still achieved and become a company that has competitive advantage.

2. Development of research to proceed to the process of designing the company's business architecture.

\section{REFERENCES}

[1] J. Ward and J. Peppard, Strategic Planning for Information Systems, 3rd ed. Chichester, West Sussex, England: John Wiley \& Sons Inc, 2002. 
[2] A. Cassidy, A Practical Guide to Information System Strategic Planning, 2nd ed. Boca Raton, Florida: Auerbach Publication, 2006.

[3] T. Pudjadi, K. Kristianto, and A. Tommy, "Analisis untuk perencanaan strategi sistem dan teknologi informasi pada PT. Ritrans Cargo," in Seminar Nasional Aplikasi Teknologi Informasi 2007 (SNATI 2007), 2017, pp. I7-I12.

[4] M. Jaana, M. Teitelbaum, and T. Roffey, "IT strategic planning in a pediatric hospital: Overview of the process and outcomes," in Proceedings of the Annual Hawaii International Conference on System Sciences, 2012, pp. 2910-2919.
[5] Y. T. Wiranti, "Perencanaan Strategis Sistem Informasi/Teknologi Informasi Pada PT. Berlian Jasa Terminal Indonesia," Institut Teknologi Sepuluh Nopember, 2015.

[6] H. Kerzner, Strategic Planning for Project Management using a Project Management Maturity Model. New York: John Wiley \& Sons, 2001.

[7] T. Efraim, R. K. Rainer, and R. E. Potter, Introduction to Information Technology. New York, USA: John Wiley \& Sons, Inc., 2003. 